\title{
ЛАНДШАФТОГЕНЕЗ КАРБОНАТНЫХ ПОРОД ВЕРХНЕМЕЛОВЫХ ОТЛОЖЕНИЙ ВОРОНЕЖСКОЙ АНТЕКЛИЗЫ
}

\author{
В. Б. Михно, А. С. Горбунов \\ Воронежский государственный университет
}

Поступила в редакцию 13 марта 2019 г.

\begin{abstract}
Аннотация: рассматривается роль карбонатных пород верхнемеловых отложений Воронежской антеклизы в формировании ландшафтов. На основе анализа материалов полевьх исследований, учета физико-механических и химических свойств мело-мергельных пород показаны отличия литоландшафтогенеза и геолого-геоморфологические особенности литогенной основы меловых ландшафтов. Приведены данные о специифике карстовой денудации. Установлена скорость подземной карстовой денудации в мело-мергельных породах Среднерусской возвышенности. Выполнена типология и раскрыты природные особенности меловых ландшафтов: обнаженных, завуалированных, покрытых и подземных, в формировании которых ведущая роль принадлежит карбонатным породам верхнемеловых отложений Воронежской антеклизы, показаны возможности использования данных, полученных о литоландшафтогенезе мело-мергельных пород, в практике природопользования и оптимизачии ландшафтно-экологической обстановки Центрального Черноземья.

Ключевые слова: литоландшафтогенез, литогенная основа, мело-мергельные породы, карстовая денудация, меловые ландшафты.
\end{abstract}

\section{THE LANDSCAPES GENESIS OF CARBONATE ROCKS OF THE UPPER CRETACEOUS DEPOSITS OF THE VORONEZH ANTECLISE}

\begin{abstract}
Upper Cretaceous deposits of the Voronezh anteclise in the formation of landscapes is considered. The differences of lithological landscape genesis, geological and geomorphological features of the lithogenic basis of Cretaceous landscapes was based on the analysis of research materials, the physicomechanical and chemical properties of Cretaceous rocks. The data on the features of karst denudation are given. The rate of underground karst denudation in the Cretaceous rocks of the Central Russian Upland is established. The typology of the cretaceous landscapes is created. The natural features of the cretaceous landscapes (exposed, veiled, covered and underground) are shown. On the base of the landscape mapping, analysis of archive materials and literature, the distribution of the main morphological and genetic types of landscapes, formed by carbonate rocks of the Upper Cretaceous deposits of the Voronezh anteclise, is considered. The possibilities of using the data of lithogenic landscape genesis, for the optimization the landscape-ecological situation of the Central Black Soil Region are shown.

Keywords: lithological landscape genesis, lithogenic basis, the Cretaceous deposits, karst denudation, the Cretaceous landscapes.
\end{abstract}

\section{Введение}

На территории Воронежской антеклизы широко распространены карбонатные породы верхнемелового возраста, приуроченные к туронскому, коньякскому, сантонскому, кампанскому и маастрихскому ярусам. Они входят в состав верхнего структурного мегакомплекса Воронежской антеклизы, образуя самостоятельный структурный этаж, состоящий преимущественно из мело-мергельных пород, мощность которых резко возрастает в юго-западном и юговосточном направлениях, достигая 200-250 м.
Литология, стратиграфия, тектоника и особенности формирования меловых отложений Воронежской антеклизы нашли отражение в ряде работ [1-6]. Это открывает возможности для установления роли карбонатных пород верхнего мела в литоландшафтогенезе. Потребность в таких исследованиях тесно связана с необходимостью решения ряда научных и практических задач [7]. Во многих местах мело-мергельные породы выходят на дневную поверхность или залегают неглубоко, образуя литогенную основу природнотерриториальных комплексов, получивших наименование «меловых ландшафтов» (рис. 1). 


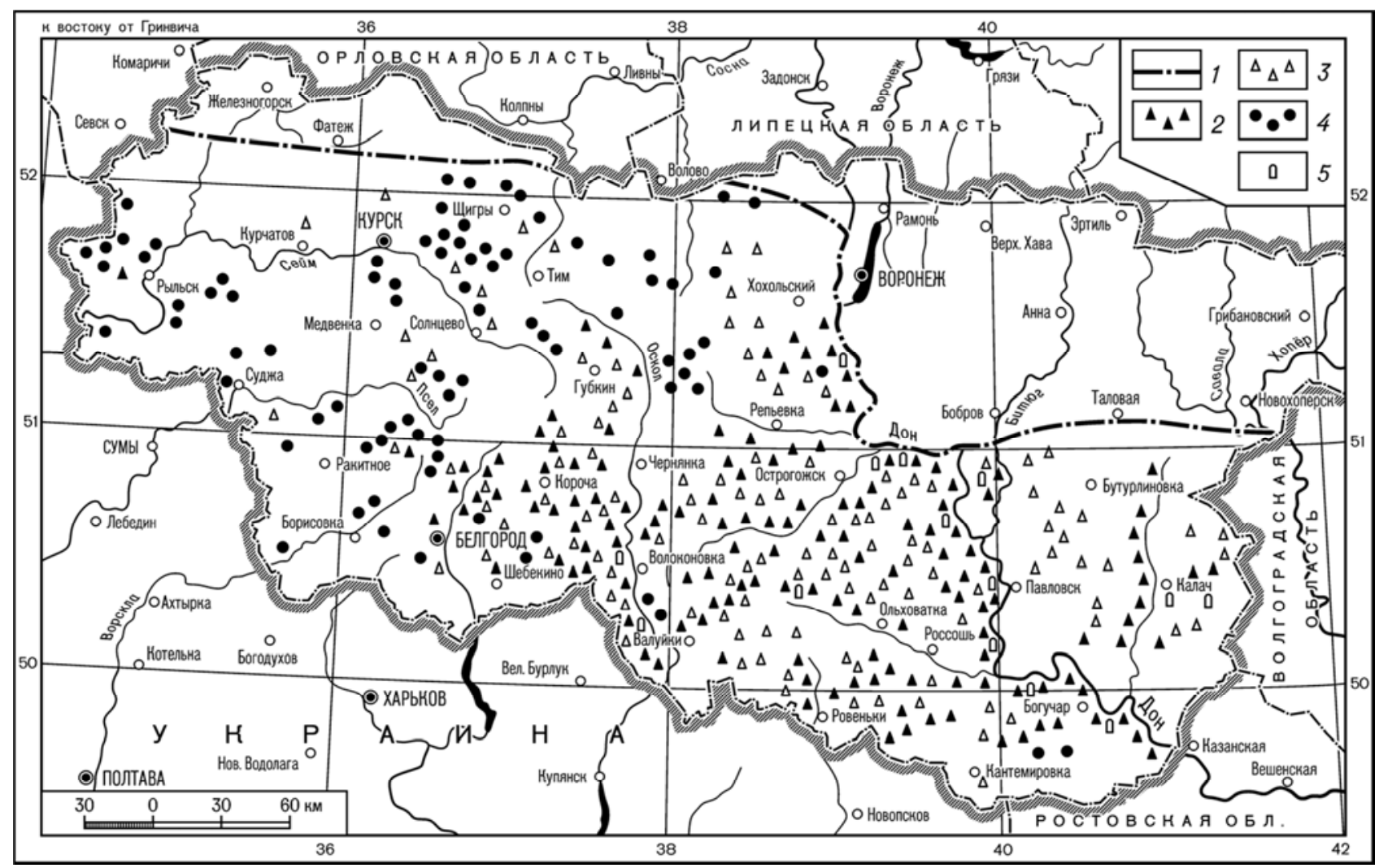

Puc. 1. Распространение меловых ландшафтов в пределах Воронежской антеклизы. Условные знаки: 1 - граница меловой области; 2 - обнаженные меловые ландшафты; 3 - завуалированные меловые ландшафты: 4 - покрытые меловые ландшафты; 5 подземные меловые ландшафты.

Установление особенностей происхождения, развития, свойств и воздействия ландшафтов, имеющих мело-мергельную основу, на экологическую обстановку приобретает все большую актуальность в связи с необходимостью территориального планирования, совершенствования системы природопользования, осуществления работ, связанных с оптимизацией ландшафтно-экологической обстановки мелового юга Центрального Черноземья.

Целью данной работы является выявление специфики литоландшафтогенеза карбонатных пород верхнемеловых отложений Воронежской антеклизы. В качестве основных задач выступают: 1) установление роли меловых пород как фактора литоландшафтогенеза; 2) определение интенсивности карстовой денудации меловых пород; 3) выявление геолого-геоморфологических особенностей литогенной основы меловых ландшафтов; 4) разработка типологии ландшафтов, имеющих карбонатную мело-мергельную основу.

\section{Методический аспект исследований}

Проблема литоландшафтогенеза привлекает внимание многих исследователей [8-10]. Однако она до сих пор окончательно не решена. При выполнении данной работы литоландшафтогенез рассматривается как процесс, предопределяющий происхождение и развитие ландшафтных комплексов под воздействием литогенных факторов [10]. В основе его лежит литогенез - совокупность природных процессов образова- ния и последующих изменений осадочных горных пород [11].

Для целей изучения ландшафтогенеза карбонатных пород верхнемеловых отложений Воронежской антеклизы применялись различные методы: ландшафтного картографирования, системного анализа, балансовых расчетов, моделирования, химического анализа. На основе крупномасштабного (1:10000) полевого картографирования и визуальных наблюдений, были составлены картосхемы распространения меловых ландшафтов, установлена их морфология, структура и генезис. Системный анализ привлекался для выявления динамических связей меловых ландшафтных комплексов. Балансовый метод был положен в основу определения скорости карстовой денудации в мело-мергельных породах. На основе картографического моделирования осуществлялась морфолого-генетическая типология меловых ландшафтов. Химический анализ проводился для новообразований погребенных карстовых форм рельефа в мелу, расположенных на территории карьера «Средний» (Воронежская область), Стойленского рудника КМА, а также на правобережье р. Девицы.

\section{Меловые породы}

\section{как фактор литоландшафтогенеза}

На территории Воронежской антеклизы меловые породы обязаны литогенезу карбонатных отложений, формирование которых связано с широкой трансгрес- 
сией, начавшейся на рубеже позднеальбско-сеноманского времени. В этот период на обширной территории Восточно-Европейской равнины в связи с уменьшением областей сноса терригенный тип седиментогенеза стал сменяться карбонатным, получившим полное развитие уже в туронско-коньякское время [2].

Мел и мергель не однородны в литологическом отношении. Они состоят из растворимой карбонатной части и нерастворимых примесей. Карбонатная часть почти всецело состоит из кальцита, в строении которого основную породообразующую роль играют кокколитофориды, принадлежащие к типу золотистых водорослей.

Нерастворимая часть мело-мергельных пород состоит преимущественно из глинистых примесей. На основе учета соотношения карбонатной составляющей и глины разработаны литологические классификации мергельных пород, включающие от 7 до 20 разновидностей.

Анализ вещественного состава мело-мергельных пород с использованием микроскопического, рентгеновского, электронно-микроскопического, химического, спектрального и других методов исследования детально раскрывает палеогеографические условия осадконакопления, разнообразие состава и особенности стратиграфии верхнемеловых отложений $[4,5,6]$.

Свойственное толще карбонатных пород верхнего мела разнообразие литотипов, с присущими им физико-механическими и химическими особенностями, играет роль ведущего фактора литоландшафтогенеза природных комплексов, имеющих мело-мергельную литогенную основу.

Мело-мергельные породы не однородны по своему химическому составу. Процентное содержание и сочетание химических элементов в них крайне невыдержанно от места к месту, что объясняется, прежде всего, спецификой физико-географических условий литогенеза конкретных территорий. Особенно большое влияние на химический состав меловой толщи оказывают процессы химической денудации и физического выветривания. В естественных обнажениях химический состав мело-мергельных пород сильно варьирует. Содержание $\mathrm{CaCO}_{3}$ в наиболее чистых толщах писчего мела достигает $99 \%$.

Вместе с тем, мело-мергельным породам присуща сильная трещиноватость, незначительная гигроскопичность, легкая диспергируемость, слабая морозоустойчивость и ничтожная водопроницаемость.

На значительной площади обнажающихся меломергельных пород Воронежской антеклизы, в их верхних горизонтах, развит элювиальный слой, представляющий собой своеобразную дресву, включающую мелкие обломки мела и тонкодисперсные частицы меловой «муки». Довольно часто измельченные частицы мела встречаются в виде гнезд и небольших линз в обнажениях плотных меловых толщ правобережья Дона, Битюга, Айдара, Северского Донца, Оскола и других рек.
Одним из наиболее существенных химических свойств мело-мергельных пород является способность их растворятся под воздействием воды, обогащенной кислотами или солями, благодаря которым вода приобретает агрессивные по отношению к этим породам свойства. Химический процесс растворения меловых пород и вынос их в виде раствора предопределяет развитие мелового карста и закарстованность толщ мело-мергельных отложений, что находит яркое отражение в морфологии ландшафтов.

\section{Ландшафтообразующая роль карстовой денудации меловых пород}

На значительной территории Среднерусской и Калачской возвышенностей мело-мергельные породы подвержены карстовой денудации, выступающей достаточно мощным фактором литоландшафтогенеза. В основании карстовой денудации лежит карст - процесс химического растворения природными водами карбонатных пород меловых отложений и выноса их в виде растворенного вещества [12].

Интенсивность растворения мело-мергельных пород в значительной мере зависит от степени насыщения воды $\mathrm{CO}_{2}$. Вода, насыщенная $\mathrm{CO}_{2}$, обладая повышенной агрессивностью, быстрее разрушает меловые породы. Наиболее интенсивно процессы растворения, a, следовательно, и карстовой денудации протекают в литологически чистых толщах мела.

Количественные показатели скорости карстовой денудации в породах мела для многих районов рассматриваемой территории еще не установлены. Объясняется это как слабой изученностью природной специфики денудации, так и отсутствием совершенных методов определения скорости химического и механического разрушения меловых пород в природных условиях.

В сложившейся ситуации для получения более точных данных целесообразно руководствоваться химическим составом вод меженного периода, когда реки имеют преимущественно подземное питание, или учитывать состав и дебит карстовых источников, дренирующих толщи растворимых пород. Учитывая, что химический состав и дебит воды многих карстовых родников рассматриваемого региона в течение года существенно не изменяются, их характеристики были использованы для определения скорости карстовой денудации на ключевых участках мелового юга Среднерусской возвышенности (табл. 1).

Для расчета скорости карстовой денудации использовался карстово-гидрометрический метод, представляющий собой модификацию метода Ж. Корбеля, выполненную А. Г. Чикишевым [13]. Скорость карстовой денудации согласно данному методу равна:

$$
C=0,0126 M T
$$

где $\mathrm{C}$ - скорость карстовой денудации, $\mathrm{m}^{3} / \mathrm{\kappa m}^{2}$ в год, или мм/тысячелетие; М - модуль стока, л/с-км²; Т - содержание в воде карбоната кальция, мг/л (установлено при помощи химического анализа воды карстовых источников). 
Таблица 1

Скорость подземной карстовой денудаиии в мело-мергельных породах Среднерусской возвыменности [12]

\begin{tabular}{|l|c|c|c|}
\hline \multicolumn{1}{|c|}{ Местоположение карстового источника } & $\begin{array}{c}\text { Содержание в воде } \\
\text { карбоната кальция, } \\
\text { мг/л }\end{array}$ & $\begin{array}{c}\text { Модуль } \\
\text { стока, } \\
\text { л/сек км }\end{array}$ & $\begin{array}{c}\text { Скорость карстовой } \\
\text { денудации, м³/км }^{2} \text {-год }\end{array}$ \\
\hline п. Нижний Кисляй (Воронежская обл.) & 282,5 & 0,50 & 1,8 \\
\hline с. Среднее (Воронежская обл.) & 248,0 & 1,35 & 4,2 \\
\hline г. Алексеевка (Белгородская обл.) & 360,8 & 0,88 & 4,0 \\
\hline г. Гремячье (Воронежская обл.): источник №1 & 202,4 & 1,20 & 3,1 \\
\hline \multicolumn{1}{|c|}{ источник № 2 } & 284,1 & 1,20 & 4,3 \\
\hline с. Ильинка (Белгородская обл.) & 253,3 & 0,90 & 2,9 \\
\hline с. Малое Быково (Белгородская обл.) & 319,6 & 0,92 & 3,7 \\
\hline с. Колодежное (Воронежская обл.) & 193,2 & 0,51 & 1,2 \\
\hline с. Белогорье (Воронежская обл.) & 220,5 & 0,47 & 1,3 \\
\hline с. Знаменка (Белгородская обл.) & 210,4 & 1,26 & 3,3 \\
\hline
\end{tabular}

Из таблицы следует, что скорость подземной карстовой денудации в мелу южных районов Среднерусской возвышенности колеблется от 1,2 до $4,3 \mathrm{~m}^{3} / \mathrm{kм}^{2}$ в год. Естественно, в местах совместного развития подземной и поверхностной карстовой денудации сработка меловых массивов происходит интенсивнее.

\section{Геолого-геоморфологические особенности литогенной основы меловых ландшафтов}

Геологические особенности литогенной основы меловых ландшафтных комплексов чаще всего предопределены способностью мело-мергельных пород растворяться и создавать полости, эволюционное развитие которых вызывает в меловых отложениях различные отклонения сейсмического, стратиграфического и литологического характера. Все это придает литогенной основе ландшафтов районов распространения мело-мергельных пород специфические черты.

Сейсмические явления. Некоторые исследователи связывают с выщелачиванием мела проявление землетрясений на юге Русской равнины. По их мнению, очаги землетрясений приурочены к крупнейшим карстовым провалам в меловой толще. Один из таких провалов вызвал 8 августа 1913 года в окрестностях г. Купянска землетрясение силой в 4 балла. Отсюда оно распространилось по долине реки Оскол до южных районов Белгородской области. Предполагается, что землетрясение произошло в результате грандиозного обвала в огромной полости, сформировавшейся в толще писчего мела [14]. Современная сейсмическая активность в пределах Воронежской антеклизы носит локальный характер, связана с активностью тектонических разломов. Амплитуда землетрясений, зафиксированных в Воронежской области, не превышает 6 баллов (MSK) [15]. Проявление сейсмичности и тектонических движений выступают в качестве важнейших факторов формирования трещиноватости меломергельных пород, способствуя их интенсивной карстовой денудации [16].

Стратиграфические нарушения. С особенностью литологии мело-мергельных пород и прежде всего способностью их растворяться тесно связаны многочисленные и разнообразные стратиграфические нарушения литогенной основы ландшафтов.

В местах карстовых провалов довольно часто можно наблюдать изогнутость горных пластов в ви- де флексур, антиклинальных и синклинальных складок. Здесь также прослеживаются микросбросы и сильные нарушения в последовательности залегания горных пород.

Литологические новообразования. Меломергельные породы в значительной мере предопределяют не только стратиграфические особенности, но и своеобразие литологических условий многих ландшафтных комплексов. Свидетельство тому - трансформация карбонатных пород зоны гипергенеза под воздействием карста и формирование современной коры выветривания.

Вещественный состав коры выветривания меломергельных пород характеризуется большой пестротой и минералогического и литологического состава. Кора выветривания обычно состоит из нерастворимых осадков, входящих в состав тех ярусов меломергельных пород, верхние слои которых были подвергнуты процессам гипергенеза. Наиболее часто она включает элювиальные глины, трепеловидные и опаловидные породы, вторичные фосфориты, бурые железняки и глауконит. Иногда встречается гипс и ангидрит. Многие породы коры выветривания обогащены различными микроэлементами и прежде всего иттрием, иттербием, стронцием, кобальтом, лантаном. В коре выветривания меловых пород и в кремнистых образованиях известны цеолиты $[4,5,6]$.

Полевые наблюдения позволяют сделать вывод, что для большей части меловой области Воронежской антеклизы мощность зоны современного гипергенеза не превышает 40 м. Наиболее активно развит этот процесс до глубины 3-5 м. На это указывает сосредоточенное здесь абсолютное большинство карстовых полостей.

Погребенный меловой карст объединяет значительную группу не отраженных в современном рельефе карстовых образований, выполненных преимущественно песчано-глинистыми отложениями. Эти формы можно наблюдать в геологических обнажениях на 
склонах оврагов, балок, речных долин и на стенах карьеров. На водораздельных пространствах многочисленные погребенные формы карста в мелу обнаружены при помощи геологического бурения и геофизических методов исследования.

Погребенные карстовые формы рельефа вскрыты в меловых карьерах вблизи г. Суджи, г. Семилук, г. Ст. Оскол, пос. Нижний Кисляй, с. Девица, а также на территории Лебединского, Южно-Лебединского и Стойленского рудников (рис. 2). Погребенные образования мелового карста можно также наблюдать на склонах Ендовищенских оврагов (бассейн р. Девицы), на левобережье р. Ворсклы у с. Томаровки, на правобережье Дона вблизи сел Сторожевое и Щучье, на левобережье Толучеевки у с. Березовки, на правом склоне балки Кисляй и др.

Погребенные карстовые формы рельефа в ряде случаев явились местом образования разнообразных полезных ископаемых: бурых железняков, фосфоритов, глинистых пород, богатых микроэлементами, и др.

Химический анализ новообразований погребенных карстовых форм рельефа, расположенных на территории карьера «Средний» (Воронежская область), Стойленского рудника КМА, а также погребенных карстовых форм рельефа правобережья р. Девицы показывает, что в их составе большую роль играют гидраты окиси железа и алюминия (табл. 2).

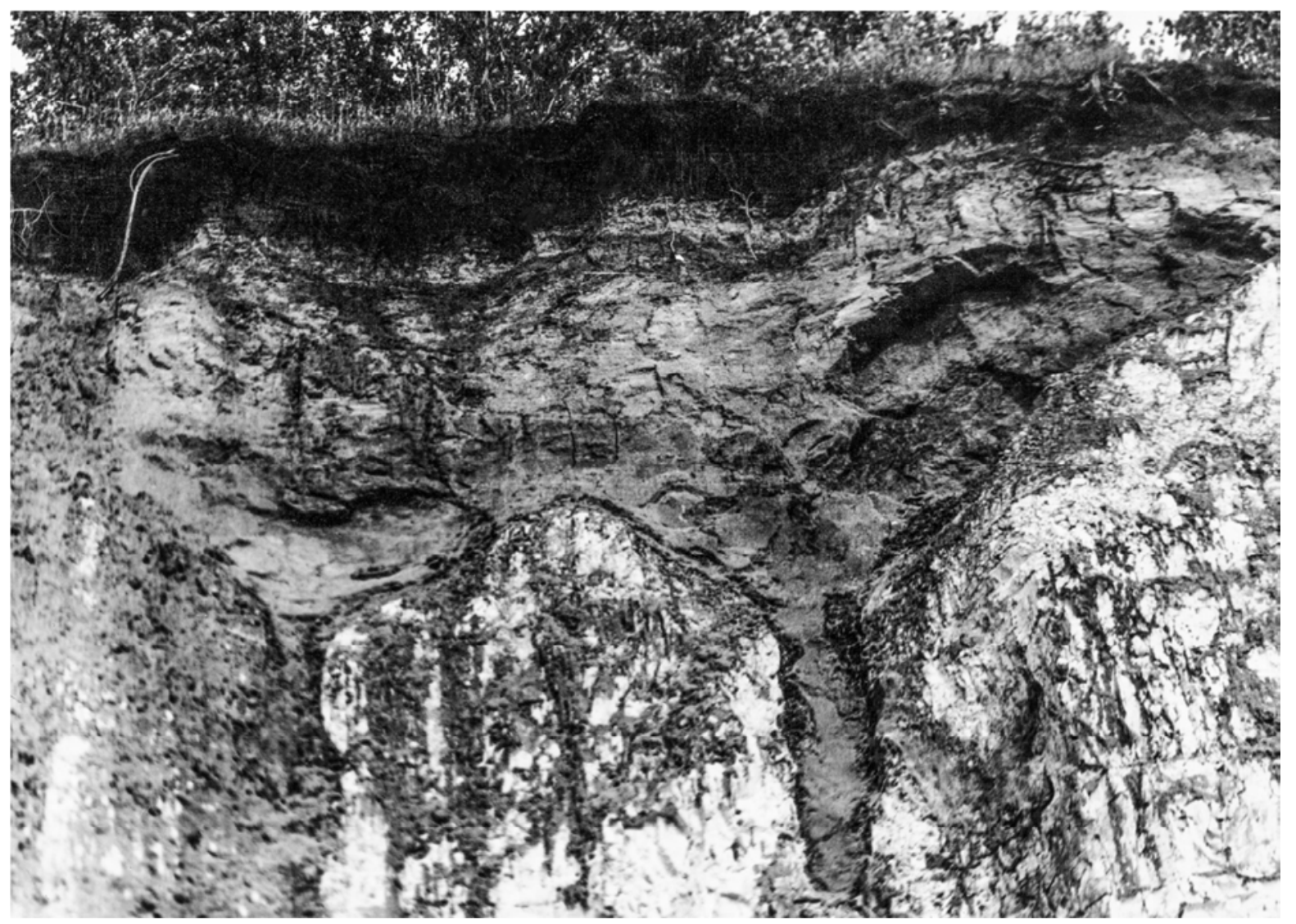

Puc. 2. Погребенные карстовые воронки в мелу, заполненные песчано-глинистыми отложениями неогенового возраста (г. Суджа, Курская область).

Таблица 2

Химический состав новообразований погребенных карстовых форм рельефа [15]

\begin{tabular}{|l|c|c|c|c|c|c|c|c|}
\hline \multirow{2}{*}{ Местонахождение } & \multicolumn{7}{c|}{ Содержание, вес \% } & \multirow{2}{*}{ Плотность } \\
\cline { 2 - 7 } & $\mathrm{SiO}_{2}$ & $\mathrm{Al}_{2} \mathrm{O}_{3}$ & $\mathrm{Fe}_{2} \mathrm{O}_{3}$ & $\mathrm{MgO}$ & $\mathrm{CaO}$ & $\begin{array}{c}\text { Потери при } \\
\text { прокаливании }\end{array}$ & \\
\hline \multicolumn{7}{|c|}{ Стойленский карьер } \\
\hline Проба 1 & 26,5 & 14,3 & 46,7 & 0,5 & 0,7 & 9,7 & 3,5 \\
\hline Проба 2 & 58,4 & 29,2 & 7,0 & 0,6 & 0,7 & 6,3 & 3,3 \\
\hline Проба 3 & 59,1 & 31,1 & 5,2 & 0,1 & 0,9 & 3,6 & 3,2 \\
\hline Проба 4 & 49,1 & 33,4 & 8,8 & 0,1 & 1,5 & 7,3 & 3,1 \\
\hline Карьер «Средний» & 48,0 & 20,0 & 5,0 & 1,0 & 11 & 15 & - \\
\hline
\end{tabular}


Таким образом, своеобразие геологической обстановки в районах распространения мело-мергельных пород выражено довольно четко. Оно проявляется, прежде всего, в большой пестроте литогенной основы ландшафтов. Литологическая неоднородность мело-мергельных пород, а также присущие им физико-химические свойства вызывают трансформацию физико-географических компонентов, предопределяющую формирование качественно новых ландшафтных комплексов.

Рельефообразующая роль меловых пород. Меломергельные породы во многих районах южной части Воронежской антеклизы выступают в роли ведущего рельефообразующего фактора. Они не только налагают отпечаток на ход развития геоморфологических процессов, но и нередко предопределяют формирование своеобразного рельефа, присущего только территориям, сложенным мело-мергельными породами. Все это находит отражение в специфике литогенной основы ландшафтов [7].

К их числу принадлежат такие особенности как приуроченность к меловым массивам карстовых воронок, западин, котловин, цирковидных балок, крупных балок - суходолов, широких речных долин и др.

Особенно значительные изменения литогенной основы меловых ландшафтов наблюдаются на интенсивно закарстованных участках. Свидетельством тому является наличие здесь крупных карстовых котловин, воронок, западин и других карстовых форм рельефа.

В изменении рельефа большую роль сыграли также процессы плоскостной карстовой денудации. При участии карстовых процессов срез верхних обнаженных горизонтов мело-мергельных пород происходит повсеместно. Глубина сработки поверхности мела под растворяющим воздействием воды в эксперименталь- ных условиях составляет от 0,4 до 1 мм в год [17]. В естественных условиях глубина среза поверхности мела под воздействием карстовых процессов меньше, чем в экспериментальных, что объясняется сравнительно небольшим периодом омывания водой меловых обнажений в течение года. Выполненные расчеты среза меловой толщи ряда районов Среднерусской возвышенности показали, что глубина сработки этих пород за счет карстовой денудации составляет от 0,002 до 0,015 мм в год [7].

Рельефообразующая роль меловых пород заметно усиливается при взаимосвязанном воздействии на них карстовых и эрозионных процессов. Эрозия и карст в мелу проявляются весьма своеобразно, оказывая большое влияние друг на друга. Взаимодействие этих процессов может быть разноплановым и осуществляться как косвенно, так и непосредственно.

Анализ морфологии и генезиса наиболее распространенных форм рельефа территорий с меломергельным субстратом позволяет выделить несколько основных типов рельефа: котловинно-западинный, долинно-балочно-овражный, останцово-грядовый и котловинно-бугристый (рис. 3).

Таким образом, рельеф и геоморфологические процессы в районах приповерхностного и поверхностного залегания мело-мергельных пород характеризуются специфическими чертами, предопределенными литологическими свойствами этих пород. Особенно сильное влияние на морфологию и геоморфологические процессы оказывают физико-химические свойства мело-мергельных пород и прежде всего способность их растворяться под воздействием воды, обогащенной минеральными и органическими кислотами. В конечном результате все это ведет к трансформации литогенной основы ландшафтов.

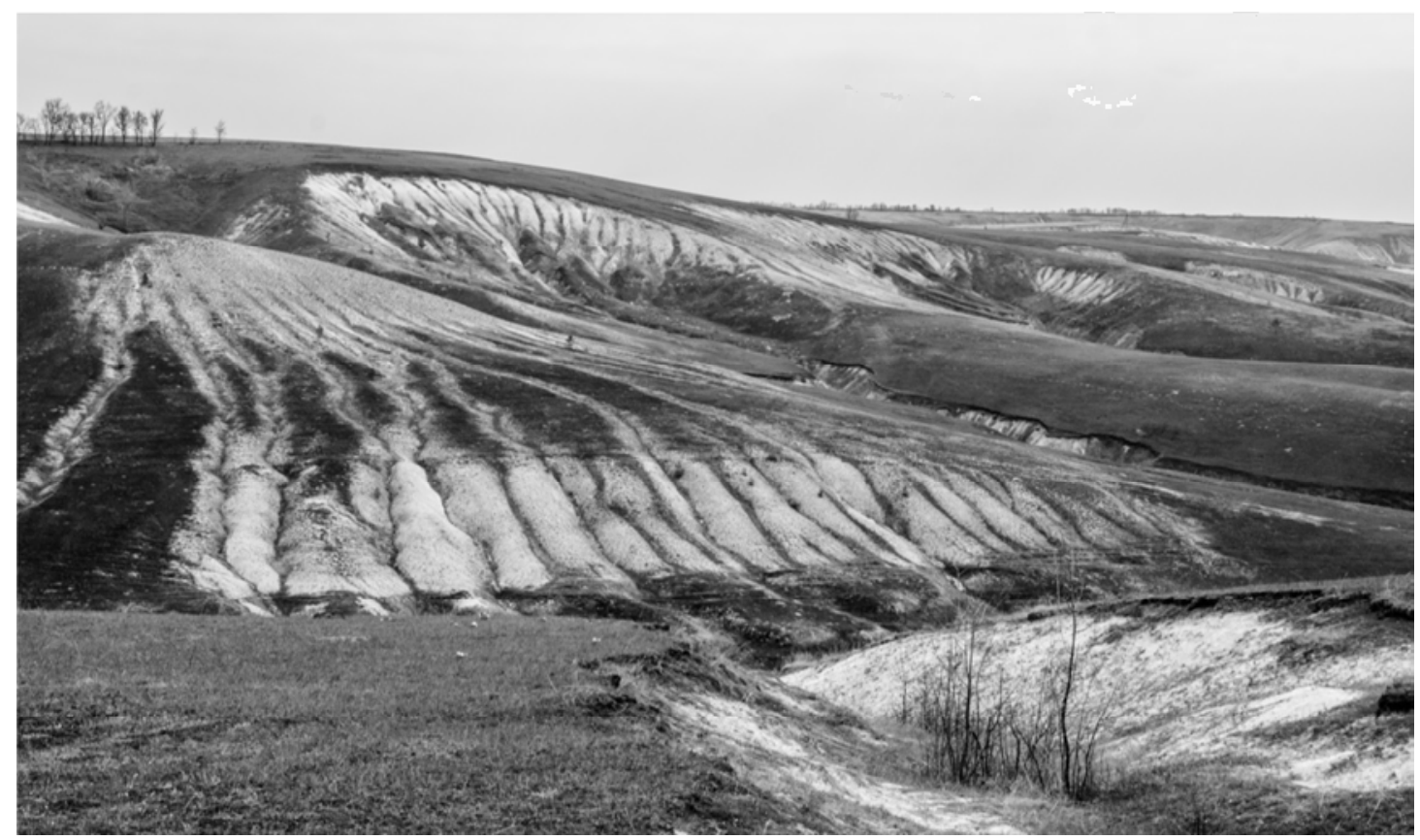

Рuс. 3. Долинно-балочно-овражный рельеф в условиях приповерхностного залегания мело-мергельных пород (Балка Лощильная, Острогожский район Воронежской области). 


\section{Типология меловых ландшафтов}

Ландшафтообразующая роль карбонатных пород верхнего мела находит яркое отражение в своеобразии физико-географических компонентов и ландшафтных комплексов, районов приповерхностного и поверхностного залегания мело-мергельных пород Воронежской антеклизы. Роль мелового субстрата в формировании физико-географических факторов, компонентов и ландшафтных комплексов носит дифференцированный характер. Многие из них не только приобрели специфические черты, но и вообще возникли благодаря тем или иным свойствам меломергельной основы.

Сформировавшиеся на меловом субстрате ландшафты отличаются большим разнообразием, хозяйственной ценностью, воздействием на экологическую обстановку. Решение многих задач, связанных пре- имущественно с рациональным природопользованием и оптимизацией экологических условий, требует учета специфики основных типов меловых ландшафтов.

Тип мелового ландшафта представляет собой совокупность меловых ландшафтных комплексов различного таксономического ранга, территориально не всегда связанных между собой, но сходных в морфолого-генетическом отношении благодаря общим условиям перекрытости меловых пород и общности обмена веществом и энергией.

В зависимости от степени перекрытости и характера взаимодействия мело-мергельных пород с поступающими к ним потоками вещества и энергии происходит формировании и дифференциация меловых ландшафтов. В рамках исследуемого региона сформировались обнаженные, завуалированные, покрытые и подземные меловые ландшафты (рис. 4).

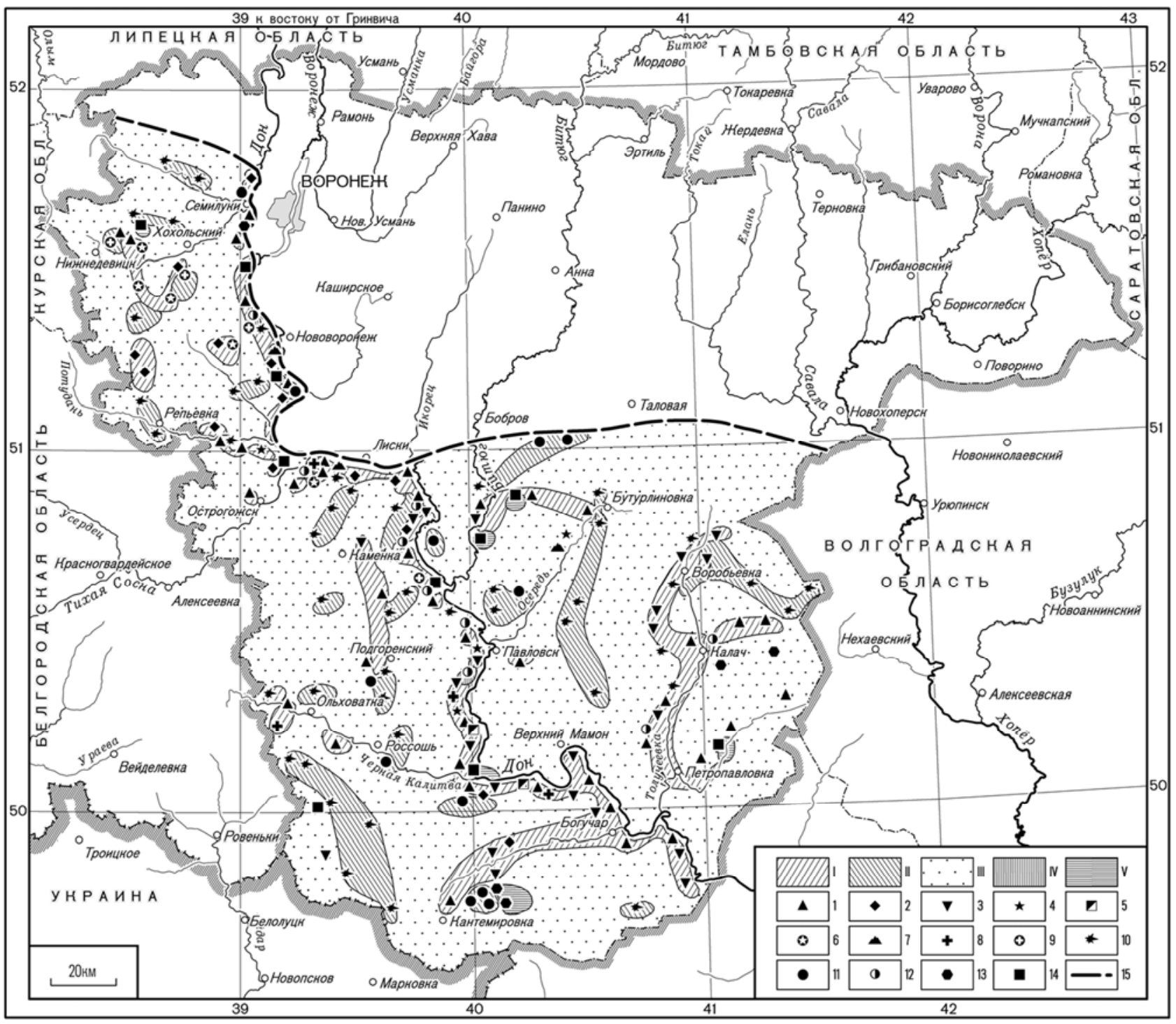

Рис. 4. Типы меловых ландшафтов Воронежской области. Условные знаки: I - Обнаженные меловые ландшафты: 1 - меловые обнажения, лишенные почвенно-растительного покрова (меловые стенки, карьеры, бедленды, пустоши); 2 - меловые обнажения с разреженными группировками иссопников на меловом делювии; 3 - меловые обнажения с группировками «сниженных альп» и тимьянников на меловом делювии; 4 - остатки меловых боров и посадки сосны на щебнистом меловом субстрате; 5 - дерезняковые меловые обнажения. II - Завуалированные меловые ландшафты: 6 - кальцефитно-петрофитные степи на меловых 
обнажениях со слаборазвитыми маломощными остаточно-карбонатными черноземами; 7 - меловые обнажения с байрачными и нагорными дубравами на попелухах и смытых серых лесостепных почвах; 8 - меловые обнажения с березняками и осинниками на смытых остаточно-карбонатных почвах. III - Покрытые меловые ландшафты: 9 - цирковидные балки в мелу с разнотравнолуговыми степями на выщелоченных и обыкновенных черноземах; 10 - воронки в мелу с древесно-кустарниковой и крупнотравной растительностью на лугово-черноземных почвах; 11 - котловины и западины в мелу с лугово-болотной растительностью на луговочерноземных почвах. $\boldsymbol{I V}$ - Подземные меловые ландшафты: 12 - пещеры, пещерные храмы, подземные выработки мела. V Аквальные меловые ландшафты: 13 - озера и искусственные водоемы в мелу; 14 - русловые, родниковые и мочажиновые меловые комплексы. 15 - граница меловой области.

Обнаженные меловые ландмафты включают в себя ПТК с обнаженным мело-мергельным субстратом, формируются они в условиях геологической открытости мело-мергельных пород, испытывая на себе исключительно-мощное влияние литогенной основы карбонатного состава, что уже было показано ранее. В генетическом отношении - это весьма разнообразные ландшафтные комплексы: эрозионные, карстовые, оползневые, абразионные, антропогенные.

Природная специфика обнаженных меловых ландшафтов заключается прежде всего в повсеместном участии в их формировании эрозионных и карстовых процессов, значительной эродированности рельефа, высокой отражательной способности и сравнительно низкой температуре субстрата, отсутствии развитого почвенного покрова, преобладании разреженных группировок кальцефитной меловой растительности (рис. 5).

Обнаженные меловые ландшафты получили широкое распространение. Приурочены они главным образом к склоновому и останцово-водораздельному типам местности. Таксономический ранг структурных обнаженных меловых ландшафтов невысок. Обычно они объединяют фации, урочища, парагенетические комплексы урочищ. Многие из них характеризуются низким бонитетом. Исключение представляют лишь урочища реликтовых меловых боров, запас древесины которых порой достигает 150-200 $\mathrm{M}^{3}$ на 1 га [7].

В настоящее время обнаженные меловые ландшафты испытывают тенденцию расширения своего ареала. Увеличение площади меловых обнаженных ландшафтов происходит как вследствие естественных, так и антропогенных факторов. Первые из них обязаны неотектоническим поднятиям, способствующим денудационному срезу чехла, экранирующего мело-мергельные породы, вторые - хозяйственной деятельности человека и прежде всего добыче полезных ископаемых, сопровождающейся вскрытием мело-мергельных пород.

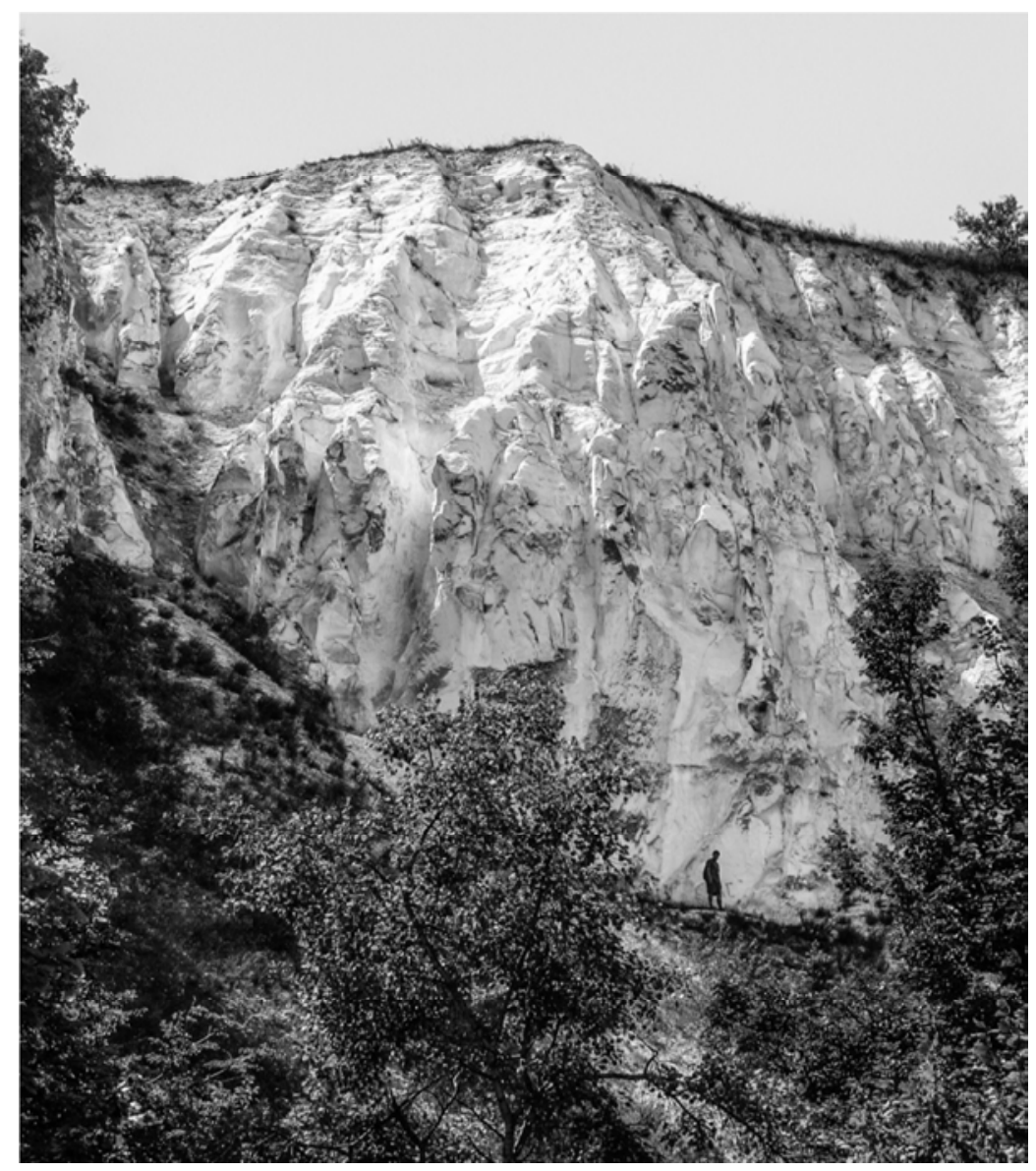

Puc. 5. Обнаженные меловые ландшафты у с. Белогорье (Воронежская обл.). 
Завуалированные меловые ландшафты развиваются в условиях перекрытости мело-мергельных пород почвенно-дерновым или элювиально-почвеннодерновым покровом. Чаще всего это тонкий (порядка нескольких сантиметров) слой остаточно-карбонатных почв, материнской основой которых являются мело-мергельные породы (рис. 6). В отличие от обнаженных, завуалированные меловые ландшафты имеют сомкнутый и более богатый в видовом составе растительный покров, в меньшей мере подвержены эрозионным и карстовым процессам, лучше обеспечены теплом и влагой. Все это в конечном итоге делает их более продуктивными по сравнению с обнаженными меловыми ландшафтами. Завуалированные меловые ландшафты занимают обширные площади в пределах склонового и останцово-водораздельного типов местности. Изредка они также встречаются на территории плакорного и зандрового типов местности. В структурном плане это преимущественно лугово-пастбищные ландшафты. В результате неумеренной пастьбы скота многие из них превратились в пастбищно-дигрессионные комплексы. В ряде районов завуалированные меловые ландшафты распаханы и используются под посевы зерновых культур.

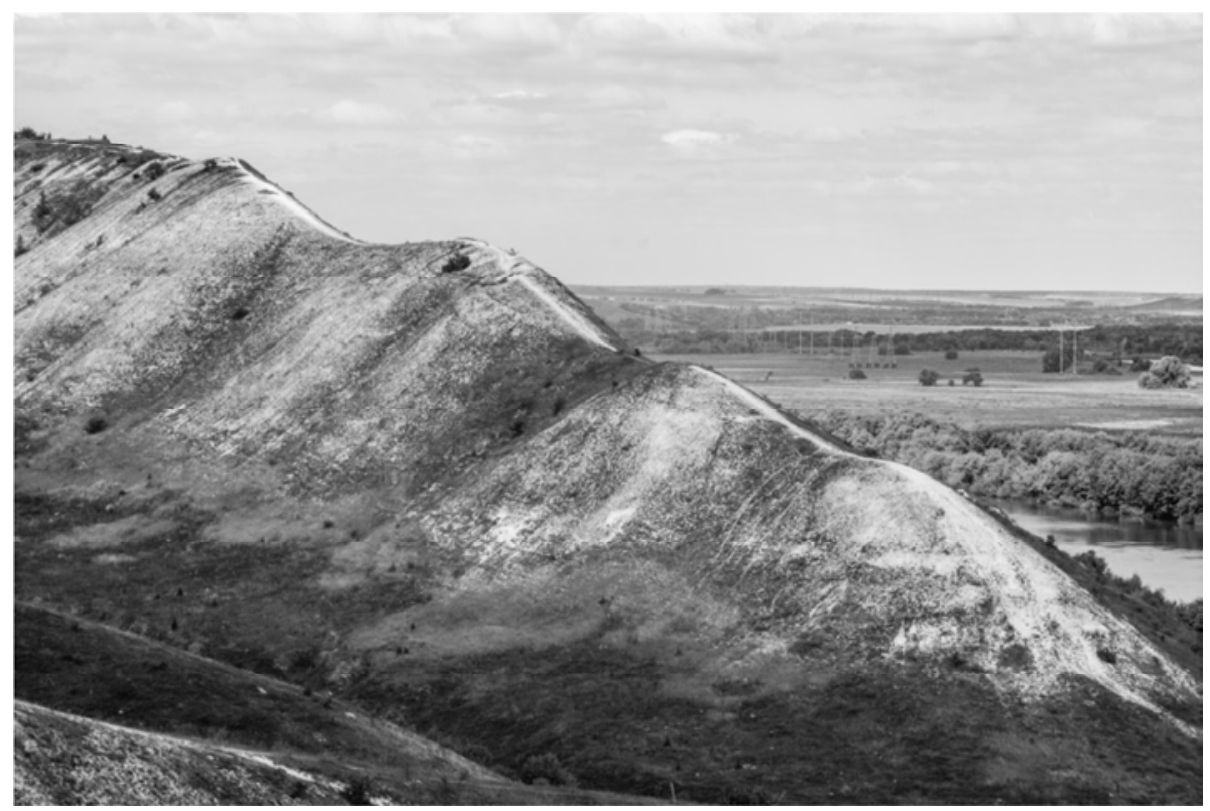

Puc. 6. Завуалированные меловые ландшафты у с. Сторожевое (Воронежская обл.). комплексы. туре карстовых ландшафтных комплексов. Однако это не означает, что литологический фактор не находит отражения в ландшафтной структуре карстовых образований. В данном случае ландшафтообразующая роль литогенной основы проявляется косвенно путем трансформации физико-географических компонентов под воздействием карстовых процессов. Часть карстовых ландшафтных комплексов покрытого типа обладает более высокой биологической продуктивностью, нежели прилежащие к ним ландшафты иного генезиса, что объясняется прежде всего лучшей увлажненностью и большим плодородием почв этих ландшафтных комплексов. В них также нередко богаче видовой состав растительного покрова и животного мира. Покрытые меловые ландшафты распространение получили на плакорном, надпойменнотеррасовом, зандровом и склоновом типах местности. Они объединяют польеобразные котловины, западины, воронки и колодцеобразные провалы. К числу доминирующих ландшафтов данного типа принадлежат лесные, болотные, озерные и лугово-степные

Подземные меловые ландшафты включают в себя природные комплексы, сформировавшиеся в подземных полостях мело-мергельной толщи. Подземные меловые ландшафты могут быть как естественного (карстового), так и антропогенного происхождения - различные подземные выработки в мелу, в том числе пещеры культового назначения.

Основными чертами подземных меловых ландшафтных комплексов является их морфологическое единство, отличие микроклиматических условий от наземных, отсутствие света, собственного почвенного и растительного покрова, наличие животных со слаборазвитым зрением, тесная зависимость развития органической жизни от потоков

Покрывные меловые ландиафты формируются в условиях перекрытости мело-мергельных пород отложениями, генетически не связанными с литогенной основой. Эту кровлю обычно образуют песчаноглинистые отложения различного возраста и генезиса. Перекрытые меловые ландшафты объединяют два генетических вида природно-территориальных комплексов - карстовые и суффозионно-карстовые. Наличие чехла нерастворимых отложений над карстующимися мело-мергельными породами приводит к тому, что влияние карбонатного субстрата растворимых пород не сказывается непосредственно на струк- вещества и энергии, поступающих со стороны наземных ландшафтов.

Таким образом, приведенная типология меловых ландшафтов свидетельствуют о своеобразии и довольно сложной структуре этих комплексов. Каждому типу меловых ландшафтных комплексов присущи свои особенности развития, распространения, морфологии и энерго-массообмена. Учет этих признаков и свойств необходим при решении прежде всего практических задач, связанных с оптимизацией меловых ландшафтов, сформировавшихся на территории Среднерусской и Калачской возвышенностей. 


\section{Выводы}

Результаты исследования ландшафтообразующей роли карбонатных пород верхнемеловых отложений Воронежской антеклизы позволяют сделать следующие выводы:

1. Мело-мергельные породы, образующие литогенную основу ландшафтов, выступают в качестве ведущего фактора формирования и развития особой категории природно-территориальных комплексов, получивших наименование «меловых ландшафтов».

2. Установлено, что литологический состав меломергельных пород существенным образом влияет не только на физико-механические и химические процессы денудации литогенного фундамента ландшафтов, но и их природные свойства на уровне фаций, урочищ, местностей.

3. На основе химического анализа воды карстовых источников определена скорость карстовой денудации в мело-мергельных породах Среднерусской возвышенности, составляющая от 1,2 до $4,3 \mathrm{~m}^{3} / \mathrm{kм}^{2}$ в год.

4. Геолого-геоморфологические особенности литогенной основы ландшафтов предопределяют их морфолого-генетическое разнообразие. Свидетельством тому является более высокое представительство типов ландшафтных комплексов, свойственных районам приповерхностного и поверхностного залегания мело-мергельных пород.

5. В зависимости от степени перекрытости и характера мело-мергельных пород на территории Воронежской антеклизы сформировалось четыре основных типа меловых ландшафтов: обнаженные, завуалированные, покрытые и подземные. Учет их специфики необходим при решении задач, связанных с рациональным природопользованием и оптимизацией экологической обстановки.

\section{ЛИТЕРАТУРА}

1. Раскатов, Г. И. Геоморфология и неотектоника Воронежской антеклизы / Г. И. Раскатов. - Воронеж: Изд-во ВГУ, 1969. $-164 \mathrm{c}$.

2. Литология и фации донеогеновых отложений Воронежской антеклизы / А. Д. Савко [и др.]. - Труды научно-исследовательского института геологии Воронеж. гос. ун-та. Вып. 3. Воронеж: Изд-во Воронеж. ун-та, 2001. - 201 с.

3. Трегуб, А. И. Неотектоника территории Воронежского кристаллического массива / А. И. Трегуб. - Труды научно-иссле- довательского института геологии Воронеж. гос. ун-та. Вып. 9. - Воронеж: Изд-во Воронеж. ун-та, 2002. - 220 с.

4. Бурыкин, В. Н. Литология и полезные ископаемые юговостока Воронежской антеклизы / В. Н. Бурыкин, А. Д. Савко. - Труды научно-исследовательского института геологии Воронеж. гос. ун-та. - Вып. 16. - Воронеж: Изд-во Воронеж. ун-та, 2003. $-100 \mathrm{c}$.

5. Дмитриев, Д. А. Сантонские отложения правобережья среднего течения реки Дон / Д. А. Дмитриев, А. Д. Савко, А. В. Жабин. - Труды научно-исследовательского института геологии Воронеж. гос. ун-та. - Вып. 21. - Воронеж: Изд-во Воронеж. ун-та, 2004. - $104 \mathrm{c}$.

6. Иванова, Е. О. Верхнемеловые отложения юго-запада ЦЧЭР (Белгородская и Курская области) / Е. О. Иванова, А. Д. Савко. - Труды научно-исследовательского института геологии Воронеж. гос. ун-та. - Вып. 64. - Воронеж: Изд-во Воронеж. ун-та, 2011. - $93 \mathrm{c}$.

7. Михно, В. Б. Меловые ландшафты Восточно-Европейской равнины / В. Б. Михно. - Воронеж: МП «Петровский сквер», 1992. - 232 с.

8. Солнцев, Н. А. Учение о ландшафте (избранные труды)/ Н. А. Солнцев. - М.: Изд-во Моск. ун-та, 2001. - 384 с.

9. Мильков, Ф. Н. Генезис и генетические ряды ландшафтных комплексов / Ф. Н. Мильков // Землеведение. 1977. - T. 12. - C. 5-11.

10. Михно, В. Б. Литоландшафтогенез, его сущность и специфика / В. Б. Михно // Вестник Воронежского отдела Русского географического общества. - Воронеж, 1999. - Т.1. вып. 1. - С. 1-7.

11. Страхов, Н. М. Основы теории литогенеза. Типы литогенеза и их размещение на поверхности Земли / Н. М. Страхов. - М.: Изд-во АН СССР, 1960. - Т.1. -212 с.

12. Михно, В. Б. Карстово-меловые геосистемы Русской равнины / В. Б. Михно. - Воронеж: Изд-во Воронеж. ун-та, 1990. $-200 \mathrm{c}$.

13. Чикишев, А. Г. Методы изучения карста / А. Г. Чикишев. - М.: Изд-во Моск. ун-та, 1973. - 92 с.

14. Федоровский, А. С. Землетрясение в купянском уезде 7.VIII.1913 / А. С. Федоровский // Изв. Постоян. центр. сейсм. комиссии. - М., 1915. - Т.6. - вып. 3. - С. 299-317.

15. Трегуб, А. И. Современные тектонические движения / А. И. Трегуб // Эколого-географический Атлас-книга Воронежской области. - Воронеж, 2013. - С. 51.

16. Трегуб, С. А. Геологические условия развития карста на территории Воронежской области / С. А. Трегуб, А. И. Трегуб // Вестник Воронеж. гос. ун-та. Сер. Геология. - 2002. № 1. - C. 254-258.

17. Максимович, Г. А. Основы карстоведения / Г. А. Максимович - Пермь, 1969. - Т. 2. -529 с.

\section{Voronezh State University}

Mikhno V. B., Doctor of Geographical Sciences, Professor of the Department of Physical Geography and Landscape Optimization, Faculty of Geography, Geoecology and Tourism E-mail: fizgeogr@mail.ru; Tel.: +7(473) 2665654

Gorbunov A. S., Candidate of Geographical Sciences, Associate Professor of the Department of Physical Geography and Landscape Optimization, Faculty of Geography, Geoecology and Tourism

E-mail: gorbunov.ol@mail.ru; Tel.: +7(473) 2665654 